\title{
KARTINI: SANG PENYIBAK FAJAR NASIONALISME INDONESIA
}

\author{
Dewi Yuliati \\ Departemen Sejarah, Fakultas Ilmu Budaya, Universitas Diponegoro \\ dewi_yuliati@yahoo.co.id
}

\begin{abstract}
This aticle presents the discussion on Kartini as an Indonesian nationalist heroine who is still becoming public debate. It is very important to trace the historical records of Kartini's activities in connection with her dreams to promote the life quality of her nation. It can be stated that Kartini has an important role to open the first gate for the rising Indonesian consciousness through her competence as a cultural diplomat by proposing her letters which were sent to her friends in the Netherlands. Finally, her dream came true when "Kartini Schools" were opened in Semarang, Bogor, Batavia, and Madiun in 1913-1914, and her ideas became the inspiring ideology of the Indonesian nationalism movements which arose after Kartini died on $17^{\text {th }}$ September 1904.
\end{abstract}

Key words: Kartini, Indonesian heroine, nationalism, cultural diplomat, humanism, education.

\section{Pendahuluan}

Sejak perempat terakhir abad XX banyak diskusi ilmiah yang membahas gejala kemerosotan karakter bangsa, terutama kemerosotan sifat dan tingkah laku yang berkait dengan kesadaran kebangsaan (nasionalisme). Sebagai contoh, banyak orang Indonesia merasa lebih bangga untuk menggunakan bahasa asing daripada bahasa Indonesia atau bahasa daerah; ada beberapa keluarga yang berkomunikasi dengan putera-puterinya dengan bahasa Inggris, sehingga putera/puteri mereka tidak mampu lagi berbahasa Indonesia secara baik dan benar; banyak orang tua yang memberi nama putera-puterinya dengan nama asing yang dianggap lebih berharga dan bermakna; banyak kesenian lokal (seni pertunjukan, seni bangun, seni suara, seni musik) yang hampir punah.

Dalam konteks diskusi tentang kemerosotan karakter bangsa, Suyatno mengatakan bahwa penggalangan nasionalisme melalui pendidikan, baik formal maupun nonformal, serta melalui penerbitan karya-karya sejarah sangat diperlukan untuk membangun nasionalisme Indonesia (Suyatno, 1985). Untuk memperkuat nasionalisme
Indonesia, Suhartono mengatakan bahwa generasi penerus harus mampu memegang teguh dan mengobarkan spirit Sumpah Pemuda 1928, karena sumpah pemuda itu menjadi simbol persatuan suku-suku bangsa di Indonesia yang saling mengikatkan diri dalam suatu Negara Bangsa (nation state) Indonesia. Pembahasan tentang kemerosotan karakter bangsa Indonesia terjadi di berbagai media: seminar, workshop, pers, televisi, radio. Dalam merespons wacana tentang degradasi karakter bangsa itu, Sartono Kartodirdjo (1993) memberi isyarat, bahwa globalisasi yang membuka peluang bagi perluasan modal asing dapat meruntuhkan nasionalisme Indonesia, karena perluasan modal asing dapat menciptakan dependency dan lebih dari itu neokolonialisme.

Cendekiawan Indonesia yang lain, Satjipto Rahardjo (1986), juga ikut mewaspadai pengaruh negatif kemajuan IPTEKS global terhadap eksistensi nasionalisme Indonesia. Menurut Satjipto, kemajuan IPTEKS memang telah mendorong masyarakat untuk memasuki suatu kondisi yang menyediakan kemudahan dan kenikmatan-kenikmatan tertentu, tetapi juga telah mendesak dan 
menghancurkan kecintaan kepada kebudayaan lokal atau nasional.

Berbasis pada pemahaman bahwa penguatan nasionalisme Indonesia dapat dilakukan terutama melalui penjelasan sejarah, dalam artikel ini diungkap kepedulian Kartini (1879-1904) terhadap kondisi sosial dan budaya pada zamannya yang sangat membelenggu kemajuan rakyat bumiputera di Hindia Belanda. Pemikiran Kartini yang dituangkan dalam surat-surat kepada para sahabatnya (Ny. Abendanon, Estelle Zeehandelaar $\{$ Stella\}, Ny. Nellie Van Kol), yang kemudian dihimpun dan diterbitkan pada tahun 1911 oleh Mr. Abendanon (Direktur Dinas Pendidikan, Agama, dan Industri Kerajinan/ Directeur van Onderwijs, Eeeredienst en Nijverheid), telah menjadi "viral" secara luas. Terbitan surat-surat Kartini yang diberi judul "Door Duiternis Tot Licht" itu telah diterjemahkan dalam bahasa Indonesia "Habis Gelap Terbitlah Terang", dan dalam bahasa Inggris "Letters of Javanese Princess." Di negeri Belanda buku tersebut sangat laku, sehingga hasil penjualan buku itu dapat digunakan untuk mendirikan "Kartinifonds" di Den Haag, negeri Belanda, dan "Kartinivereeniging" di Semarang. Penggalangan dana yang dilakukan oleh "Kartinifonds" dan "Kartinivereeniging"digunakan untuk mendirikan sekolah-sekolah bagi kaum perempuan bumiputera di Hindia Belanda. Pada tanggal 15 September 1913 telah dibuka Sekolah Kartini yang pertama di Semarang, kemudian pada tahun 1914 juga didirikan sekolah-sekolah Kartini di kotakota lainnya, yaitu di Bogor, Batavia, dan Madiun.1

Selain mendorong pertumbuhan sekolah-sekolah untuk kaum perempuan, pemikiran-pemikiran Kartini juga telah menjadi pemantik pembentukan organisasi-organisasi perempuan, antara lain: Putri Mardika (1912), yang menjadi bagian dari Budi Utomo, bertujuan untuk memberikan bimbingan dan penerangan kepada kaum perempuan bumiputera agar mampu menuntut ilmu dan mampu menyatakan pendapat di muka umum. Organisasi wanita lainnya adalah Kautaman Istri, didirikan oleh Raden Dewi Sartika pada tahun 1913 di Tasikmalaya, dan sebagainya. $\underline{5}$

Atas sumbangan pemikiranpemikirannya yang telah membangkitkan kesadaran kebangsaan rakyat bumiputera itu, khususnya kaum perempuan, Kartini telah ditetapkan sebagai Pahlawan Nasional melalui Surat Keputusan Presiden Soekarno No. 108 tahun 1964. Meskipun dalam realitas sejarah, Kartini telah ditetapkan sebagai Pahlawan Nasional, ada pula pihak yang tidak menerima Kartini sebagai pahlawan, karena menganggap Kartini sebagai "buatan penjajah Belanda". Pendapat ini dilontarkan oleh Harsya W. Bachtiar dalam artikelnya "Kartini dan Peranan Wanita dalam Masyarakat Kita", yang dimuat dalam buku "Satu Abad Kartini (1879-1979)". Harsya berpendapat bahwa kita mengambilalih Kartini sebagai simbol emansipasi wanita di Indonesia dari orang-orang Belanda, tidak menciptakan sendiri simbol budaya itu. $\underline{6}$

Berdasarkan latar belakang permasalahan di atas, dalam makalah ini disajikan pembahasan yang berbasis pada pertanyaan utama, yaitu: 1) Kapankah nasionalisme (kesadaran kebangsaan) Indonesia mulai muncul? 2) Mengapa Kartini ditetapkan sebagai Pahlawan Nasional Indonesia?

\section{Pembahasan}

\subsection{Nasionalisme sebagai suatu Konsep Ideologi}

Nasionalisme dapat dipahami dari sudut pandang antropologi dan politik. Dalam dimensi antropologi, nasionalisme dipandang sebagai sistem budaya yang mencakup kesetiaan, komitmen, emosi, perasaan kepada bangsa dan negara, dan rasa memiliki bangsa dan negara itu. Dalam dimensi ini, Benedict Anderson mengatakan bahwa nation (bangsa) adalah suatu komunitas politik yang terbatas dan beradaulat yang dibayangkan (imagined 
communities). Komunitas politik itu dikatakan sebagai imagined communities sebab suatu komunitas tidak mungkin mengenal seluruh warganya, tidak mungkin saling bertemu, atau saling mendengar. Akan tetapi, mereka memiliki gambaran atau bayangan yang sama tentang komunitas mereka. Suatu bangsa dapat terbentuk, jika sejumlah warga dalam suatu komunitas mau menetapkan diri sebagai suatu bangsa yang mereka angankan atau bayangkan. $\underline{7}$ Karena komitmen dan keinginan untuk mengikatkan diri dalam komunitas bangsa ini, dapat muncul kesetiaan yang tinggi pada nation state (negara kebangsaan). Bahkan, banyak warga suatu negara bangsa (nation state) rela mengorbankan jiwa-raga untuk membela bangsa dan negara mereka. Senada dengan Benedict Anderson, Ernest Renan mengatakan bahwa unsur utama dalam pembentukan suatu bangsa adalah le desir de'etre ensemble (keinginan untuk bersatu).

Pada awal abad ke-20 pemahaman rakyat bumiputera Indonesia tentang nasionalisme sebagai konsep ideologis masih sangat "samar-samar" bagaikan "alam fajar", mereka belum memiliki tujuan yang jelas, dan apa yang harus mereka lakukan untuk negeri dan bangsanya. Salah satu contoh adalah pernyataan Abdoel Moeis, seorang tokoh Sarekat Islam, yang mengartikan nasionalisme sebagai perasaan cinta kepada bangsa dan tanah air, yang diungkapkannya pada harian Sinar Djawa, 25 Oktober 1917 sebagai berikut:

Kalaoe kita mengingat akan nasib boeroeknja tanah air dan bangsa kita, jang beratoes tahoen selaloe berada dalam koengkoengan orang lain sadja, maka berdebarlah dada, timboellah soeatoe perasaan jang menggojang segala oerat saraf kita, perasaan kasihan kepada bangsa dan tanah air itoe $\underline{\mathbf{9}}$

Dalam dimensi politik, nasionalisme merupakan ideologi yang meyakini bahwa kesetiaan tertinggi individu harus diserahkan kepada negara bangsa, yaitu suatu negara yang mampu menjamin seluruh warga bangsanya untuk mendapatkan hak dan kewajiban yang sama serta mampu membuat warga bangsanya mau mengikatkan dirinya pada negara itu.10 Soekarno, presiden pertama Indonesia, mengatakan bahwa bangsa adalah sebuah konstruksi yang dihasilkan oleh sebuah visi yang diperjuangkan, Dalam pengertian politik ini, prinsipprinsip utama dalam nasionalisme adalah liberty, unity, equality, dan identitas national, yang menjadi orientasi kehidupan kolektif suatu kelompok untuk mencapai tujuan politik, yaitu negara bangsa. Sebagai doktrin politik, nasionalisme merupakan basis serta pembenaran ideologis bagi setiap bangsa di dunia untuk mengorganisasi diri dalam entitas-entitas yang bebas atau otonom, dan entitas itu berbentuk negara bangsa yang merdeka.11

Sebagai suatu konsep politik, nasionalisme digali dan dirumuskan pertama kali oleh orang-orang Eropa dalam ruang lingkup masyarakat Eropa. Doktrin nasionalisme berasal dari lingkungnan masyarakat Jerman pada abad ke-18, dan dalam pergolakan luas di Eropa yang disebabkan oleh Revolusi Perancis. Meskipun nasionalisme sebagai ideologi berasal dari Barat, perlu juga dipahami bahwa secara budaya, nasionalisme itu merupakan gejala historis yang bersifat universal, yang muncul di semua ruang bangsa. Bagaimana gejala awal pertumbuhan nasionalisme di Indonesia, hanya dapat dijawab melalui pemahaman terhadap sejarah kemunculan kesadaran berbangsa.

Untuk menjelaskan awal kemunculan nasionalisme Indonesia itu, diperlukan pemahaman terhadap situasi kolonial pada akhir abad ke-19 dan awal abad ke-20. Pada saat itu ikatan tradisi dan feodalisme serta diskriminasi masih sangat membatasi aktivitas dan ruang gerak bangsa bumiputera di Hindia Belanda (Indonesia), padahal di sisi lain sudah lahir 
golongan terpelajar bumiputera yang telah memiliki kesadaran untuk membebaskan diri dari belenggu tradisi feodalisme dan mempunyai kesadaran untuk mengadakan gerakan perlawanan terhadap kolonialisme. Dalam hal ini, Kartini adalah seorang perempuan bumiputera pertama yang melontarkan pemikirannya secara tertulis mengenai berbagai gejala sosial-budaya yang menurutnya merupakan pembelenggu kemajuan rakyat bumiputera.

Kartini, dalam usianya yang masih sangat muda itu, mampu merumuskan pemikiran-pemikirannya tentang apa yang harus dilakukan untuk bangsanya. Ia berjuang dalam kesendirian, dalam pingitan, sehingga cita-citanya untuk kemajuan bangsanya hanya dapat dituliskan dalam surat-suratnya kepada pihak-pihak Belanda, bangsa asing yang ketika itu menguasai Hindia Belanda (Indonesia). Kartini memiliki ide-ide yang cemerlang dan bermakna untuk kemajuan bumiputera di Hindia Belanda, dan juga kemampuan menulis dengan karakter sastra yang indah. Dengan demikian, ideidenya itu telah menjadi issue besar pada zamannya.

Ekspresi gagasan Kartini dalam surat-suratnya itu dapat dikategorikan sebagai upaya "diplomasi kebudayaan" yaitu serangkaian tindakan yang berbasis pada penggunaan pertukaran ie-ide, nilainilai, tradisi dan aspek-aspek budaya yang lain. Unsur-unsur budaya semacam itu digunakan untuk memperkuat hubungan kooperatif sosio-kultural dan memajukan kepentingan-kepentingan bangsa. $\underline{12}$ Diplomasi kebudayaan dapat dilakukan oleh pemerintah, lembaga-lembaga nonpemerintah, individu, atau organisasiorganisasi.13 Diplomasi ini telah dilakukan selama ratusan tahun, dan bukti-buktinya dapat diketahui melalui sejarah, seperti para penjelajah, pedagang, para guru, dan seniman (sirkus, musisi, penari, penyanyi). Mereka itu adalah "informal ambassadors" yang membentuk media pertukaran, yang dilakukan melalui berbagai bidang kebudayaan seperti olah raga, sastra, musik, ilmu pengetahuan, ekonomi, dan sebagainya.

\subsection{Kartini: Peretas Belenggu Adat dan Tradisi}

\subsubsection{Perlawanan Terhadap Poligami}

Setiap tanggal 21 April, di Indonesia selalu diadakan perayaan peringatan hari lahir Kartini, seorang perempuan Indonesia yang telah dinobatkan sebagai pahlawan bangsa. Kartini adalah seorang puteri dari R.M. Adipati Ario Sosroningrat, bupati Jepara, lahir pada tanggal 21 April 1879 di Mayong, kabupaten Jepara. Sampai dengan usia 12 tahun, Kartini masih diizinkan untuk bersekolah dan ke luar rumah oleh ayahnya. Akan tetapi, pada tahun 1892, ia harus menjalani pingitan, yang ketika itu merupakan adat Jawa yang diterapkan bagi kaum perempuan yang beranjak dewasa. Menurut pantauan J.H. Abendanon, Directeur van Onderwijs, Eeredienst en Nijvrheid, untuk mengembangkan sekolahsekolah bagi anak-anak perempuan bumiputera sangat sulit, karena anak-anak yang berusia antara 10-12 tahun harus masuk pingitan sampai ada yang meminang mereka untuk menikah. 14

Setelah dibebaskan dari kungkungan itu, Kartini pun harus menghadapi keharusan untuk menikah dengan laki-laki yang tidak dikenalnya, yaitu R. Adipati Djojo Adiningrat, bupati Rembang yang sudah memiliki 3 orang istri. Sebenarnya, Kartini sangat menentang adat perkawinan semacam itu, tapi tiada daya, karena di sisi lain ia harus patuh kepada kedua orang tuanya yang amat disayanginya. Kepatuhan kepada orang tua adalah nilai yang harus ditaati oleh perempuan Jawa, dan menikah dengan pria atas pilihan orang tuanya merupakan adat dan keharusan yang harus dijalani oleh perempuan Jawa pada saat itu.

Kartini berjuang dalam fase nasionalisme Indonesia yang paling awal. Rasa kepedulian terhadap bangsanya hanya diperjuangkannya sendiri, tanpa dukungan organisasi massa yang pada masa itu 
memang belum ada. Kesadaran akan nasib bangsanya dapat disimak antara lain melalui perlawanannya terhadap poligami yang pada saat itu membudaya di kalangan masyarakat Jawa. Dalam suratnya kepada sahabatnya, Zeehandelaar, Kartini mencurahkan perasaannya sebagai berikut.

Sekali-sekali aku tiada dapat menaruh cinta. Jika akan bercinta, menurut pendapatku, haruslah ada rasa hormat dulu. Aku tiada dapat menghormati anak muda Jawa. Bagaimana aku dapat menghormati orang yang sudah kawin dan sudah jadi bapak, tetapi karena sudah puas beristrikan ibu anak-anaknya, membawa perempuan lain ke dalam rumahnya, perempuan yang dikawininya dengan sah menurut hukum Islam? Siapa yang tidak berbuat demikian? Dan mengapa pula tidak akan berbuat demikian? Hal itu bukan dosa, dan bukan celaan pula. Hukum Islam mengizinkan laki-laki menaruh empat orang perempuan. Meskipun orang mengatakan seribu kali bahwa beristri empat itu bukan dosa menurut hukum Islam, tetapi aku mengatakan bahwa itu dosa. Segala perbuatan yang menyakitkan sesamanya, dosalah menurut pendapatku. Betapakah azab sengsara yang harus diderita seorang perempuan, bila lakinya pulang ke rumah dengan perempuan lain dan perempuan itu harus diakuinya sebagai istri lakinya yang sah, dan harus diterimanya sebagai saingannya? Perempuan itu boleh disiksanya, disakitinya selama hidup sepuas hatinya, tetapi bila ia tidak hendak membebaskan perempuan itu kembali, perempuan itu hanya bisa menangis setinggi langit untuk meminta hak, tiada jua akan dapat.

Mengertikah engkau sekarang apakah sebabnya aku sangat benci akan perkawinan? Kerja yang serendah-rendahnya maulah aku mengerjakannya dengan besar hati dan dengan sungguh-sungguh, asalkan aku tidak usah kawin, dan aku bebas. Stella, tahukah engkau, betapa sedihnya hati. Hati ingin benar berbuat sesuatu, tetapi diriku merasa sungguh tidak berdaya untuk berbuat begitu.

Engkau bertanya, apakah asal mulanya aku terkurung dalam empat tembok tebal. Sangkamu tentu aku tinggal dalam terungku atau yang serupa itu. Bukan, Stella, penjaraku adalah rumah besar, berhalaman luas di sekelilingnya, tetapi di sekitar halaman itu ada tembok tinggi. Tembok inilah yang menjadi penjara kami. Bagaimana juga luasnya rumah dan pekarangan kami itu, bila harus senantiasa harus tinggal di sana, sesak juga rasanya. Teringat aku, betapa aku, karena putus asa dan sedih yang tiada terhingga, lalu menghempaskan badanku berulangulang pada pintu yang senantiasa tertutup itu, dan pada dinding batu bengis itu. Arah ke mana juga aku pergi, setiap kali putus juga jalanku oleh tembok batu atau pintu terkunci.

Seluruh dunia kami bumiputera tentu akan berubah juga. Masa perubahan sudah ditakdirkan oleh Allah, tetapi apabilakah? Itulah yang menjadi masalah. Datangnya waktu perubahan tidak dapat kami percepat. Kawan, di sini kami berkata, alangkah baiknya jika kami tidur dulu selama seratus tahun, dan ketika kami bangun kembali, barulah kami merasa sesuai dengan keadaan pada masa itu.

Betapa pun Kartini meratapi dan menentang adat itu, kungkungan adat dan tradisi di lingkungnan keluarganya lebih kuat. Ia harus menyerah, karena rasa sayang dan kepatuhannya kepada orang 
tuanya. Pada tanggal 8 November 1903 Kartini harus menikah dengan bupati Rembang, R. Adipati Djojo Adiningrat, yang sudah memiliki 3 orang istri. Pada tanggal 13 September 1904 puteranya lahir, dan empat hari kemudian pada 17 September 1904 Kartini wafat. Kartini adalah perempuan yang memiliki intuisi yang tajam. Hal ini terbukti bahwa pada saat menjelang wafat, pada 24 Agustus 1904 Kartini sempat berpamitan kepada Ny. Abendanon dalam surat sebagai berikut.

Ibuku manis sayang. Surat yang ibu terima baru-baru ini bukanlah surat yang penghabisan. Sudahlah saya takutkan, tetapi surat ini bolehlah menjadi surat yang penghabisan, karena ajalku hampir sampai dengan cepatnya; yang demikian itu ada kurasa. Ibuku, boleh jadi benar cucu Ibu itu akan datang dahuluan daripada persangkaan kami. Terimalah salam saya, biji mataku.....

\subsubsection{Kartini: Meratapi Konflik Sosial Karena Agama}

Pada masa kehidupan Kartini, konflik karena agama tampak telah menggejala dalam masyarakat Jawa. Antartetangga, antaranggota keluarga, antarkelompok, saling bermusuhan karena perbedaan agama dan keyakinan. Kondisi ini dapat diketahui antara lain dari curahan hati Kartini dalam suratnya kepada Zeehandelaar sebagai berikut.

Agama itu maksudnya akan menurunkan rahmat kepada manusia, supaya ada silaturachim segala mahluk Allah. Kita sekalian bersaudara, bukan karena kita seibu sebapa, ialah ibu bapa kelahiran manusia, melainkan kita semuanya mahluk seorang Bapak, kepadaNya, yang bertahta di atas langit. Ya Tuhanku, ada kalanya aku berharap, alangkah baiknya jika tidak ada agama itu, karena agama itu, yang sebenarnya harus mempersatukan semua hamba Allah, sejak dari dahulu menjadi pangkal perselisihan dan perpecahan, menjadi sebab perkelahian, berbunuh-bunuhan yang sangat ngeri dan bengisnya. Orang yang seibu-sebapak berlawanan, karena berlainan cara mengabdi kepada Tuhan Yang Esa itu. Orang yang berkasih-kasihan dengan amat sangatnya, dengan amat sedihnya bercerai-cerai, karena berlainan tempat menyeru kepada Tuhan, Tuhan yang itu juga; berdirilah tembok pembatas hati yang berkasihkasihan. Benarkah agama itu restu bagi manusia? Tanyaku kerap kali kepada diriku sendiri, dengan bimbang hati. Agama harus menjaga kita dari berbuat dosa, tetapi berapa banyaknya dosa diperbuat orang atas nama agama itu?

\subsubsection{Kartini: Pelopor Pendidikan Perempuan Indonesia}

Kartini juga memperjuangkan perbaikan kehidupan rakyat bumiputera melalui pendidikan perempuan. Setelah menikah dengan Bupati Rembang, R. Adipati Djojo Adiningrat, ia mendirikan sekolah perempuan di lingkungan Kabupaten Rembang. Mendirikan sekolah bagi perempuan memang sudah menjadi keinginannya jauh sebelum Kartini menikah. Keinginannya itu pernah dituliskan dalam suratnya kepada Nyonya Abendanon, tertanggal 21 Januari 1901.

Telah lama saya memikirkan perkara pendidikan, terutama dalam beberapa waktu yang terakhir ini. Pendidikan saya pandang sebagai kewajiban yang mulia dan suci. Saya pandang sebagai suatu kejahatan, jika saya melaksanakan usaha mendidik itu, tetapi saya belum mempunyai kecakapan yang penuh. Haruslah ternyata dulu, apakah saya sudah sanggup menjadi pendidik atau tidak. Menurut pendirian saya, pendidikan itu adalah pendidikan budi dan jiwa. 
Rasa-rasanya kewajiban seorang pendidik belumlah selesai jika ia hanya mencerdaskan pikiran saja. Ia harus juga bekerja mendidik budi meskipun tidak ada hukum yang mewajibkan berbuat demikian. Saya bertanya kepada diri saya sendiri: sanggupkah saya? Saya yang masih perlu juga dididik ini?

Perempuan itu jadi soko guru peradaban!". Bukan karena perempuan dipandang cakap untuk itu, melainkan karena saya sungguh yakin bahwa dari perempuan itu akan timbul pengaruh yang besar akibatnya, baik memburukkan maupun membaikkan kehidupan. Dialah yang lebih dapat membantu memajukan kesusilaan manusia.

Dari perempuanlah pertama-tama manusia menerima didikannya. Di haribaannyalah anak itu belajar merasa, berpikir, dan berkata-kata. Makin lama makin tahulah saya, bahwa didikan yang mula-mula itu bukan tidak besar pengaruhnya bagi kehidupan manusia di kemudian hari. Betapakah ibu bumiputera itu sanggup mendidik anaknya, jika mereka sendiri tidak berpendidikan?

Karena itulah saya sangat gembira akan maksud mulia untuk menyediakan pendidikan dan pengajaran bagi gadis-gadis bumiputera. Sudah sejak lama saya maklum, bahwa itulah yang dapat mengubah kehidupan kami perempuan bumiputera yang sedih ini. Pengajaran bagi gadis-gadis itu bukan kepada perempuan saja akan mendatangkan rahmat, melainkan juga kepada seluruh masyarakat bumiputera.

Karena saya yakin sedalamdalamnya bahwa perempuan dapat memberi pengaruh besar kepada masyarakat, maka tidak ada yang lebih saya inginkan daripada menjadi guru, supaya kelak dapat mendidik gadis-gadis dari para pejabat tinggi kita.

Sekali-kali kami tidak ingin membuat murid-murid kami menjadi orang-orang setengah Eropah atau orang Jawa-Eropah. Dengan pendidikan, kami bermaksud pertama-tama membuat orang Jawa menjadi orang-orang Jawa Sejati, yang menyala-nyala dengan cinta dan semangat terhadap nusa dan bangsanya, terbuka dengan mata dan hati terhadap keindahan serta kebutuhannya. Kami hendak memberikan kepada mereka segala yang baik dari kebudayaan Eropah, bukan untuk mendesak atau mengganti keindahan mereka sendiri, melainkan untuk menyempurnakannya. $\underline{18}$

\subsubsection{Keprihatinan Kartini akan Kebiasaan Nyandu dan Minuman Keras}

Pada akhir abad ke-19 penduduk di Pulau Jawa telah dilanda kebiasaan madat/nyandu dan minum minuman keras. Orang-orang Belanda menyukai gin (minuman beralkohol), sedangkan orangorang Cina dan Jawa lebih memilih menghisap opium. Bagi orang-orang Cina, opium merupakan suguhan kehormatan besar untuk para tamunya. Pasar terbesar opium adalah orang-orang Jawa, termasuk para seniman, pedagang, tukang-tukang, dan para pekerja di perkebunanperkebunan atau perusahaaan-perusahaan swasta lainnya. Di kalangan bangsawan Jawa, opium juga menjadi simbol keramahan dan kehormatan dalam pestapesta serta dalam pergaulan. 19 Peredaran opium ini mendapat legalitas dari pemerintah kolonial Belanda, terutama melalui sistem lelang dan kontrak. Dari sistem lelang dan kontrak itu, pemerintah kolonial memperoleh pajak yang sangat besar. Sebagai contoh, pajak yang diperoleh dari bandar Semarang berjumlah 
26 juta gulden pada tahun 1881, dan terus meningkat pada tahun-tahun berikutnya. $\underline{20}$ Dengan demikian, pada zaman kolonial Belanda, masalah opium berada dalam "lingkaran" yang sulit ditemukan titik keluarnya. Kartini hanya mampu menuliskan keprihatinannya dalam surat kepada Zeehandelaar, itu pun dengan permohonan "maaf".

Saya kuatir, saya kuatir apabila nanti - maafkan saya - peradaban Barat telah berkedudukan tetap di sini, kami terpaksa pula berjuang dengan kejahatan itu. Peradaban memberi berkah, tetapi ada pula buruknya. Pikiran saya, suka meniru itu sudah menjadi tabiat manusia.

Orang kebanyakan meniru kebiasaan orang baik-baik; orang baik-baik itu meniru perbuatan orang yang lebih tinggi lagi, dan mereka itu meniru yang tertinggi pula - ialah orang Eropah. Perhelatan bukan perhelatan namanya, jika tidak ada minuman kerasnya.

Di negeri saya ini ada suatu kutuk, lebih jahat lagi daripada minuman keras itu! Candu! Alangkah sengsaranya negeri bangsaku oleh benda laknat itu, tiada dapat dikatakan. Candu itu adalah penyakit sampar pulau Jawa. Bahkan lebih ganas lagi dari sampar itu.

Benar juga kata orang: candu itu tiadalah jahat, selama ada uang pembeli racun itu, tetapi bila tiada dapat menghisap lagi, tiada uang membelinya, sedangkan badan susdah menjadi hamba madat, maka sangatlah berbahaya orang itu, celakalah dia! Oleh perut lapar orang menjadi pencuri, tetapi oleh ketagihan candu, orang menjadi pembunuh.Kata orang di sini: mulamula candu itu menjadi nikmat bagi engkau, tetapi kesudahannya dialah yang menelan engkau.

Aduh Tuhan, Ya Tuhan, sedih hati melihat kejahatan sebanyak itu di sekeliling diri, sedang diri tiada berdaya akan menjauhkannya.

\section{Simpulan}

Sepanjang sejarah, bangsa Indonesia tidak pernah luput dari pengaruh kebudayaan asing, baik melalui adaptasi maupun adopsi. Dalam kenyataan sejarah, harus diakui bahwa bangsa Indonesia telah mengambilalih sistem pengetahuan atau kebudayaan asing untuk mengembangkan kebudayaan sendiri. Sistem pendidikan, sistem pemerintahan, kesenian, dan lain-lain adalah hasil adaptasi atau adopsi dari kebudayaan India, Arab, Cina, Barat, dan Jepang.

Kartini pun merupakan produk pendidikan ala Barat, seperti yang juga diwarisi oleh orang-orang Indonesia pada masa sekarang. Apakah dengan begitu orang-orang berpendidikan Barat yang sudah ditetapkan sebagai Pahlawan Nasional seperti Tjipro Mangunkusumo, Sutomo, Dewi Sartika, Ki Hajar Dewantoro, Gunawan, HOS Tjokroaminoto, Abdul Muis, dan Soekarno adalah juga "tokoh-tokoh reka yasa Belanda?" Tidak dapat disangkal bahwa tokoh-tokoh tersebut adalah Pahlawan Nasional. Jadi tidaklah tepat, jika ada yang mengatakan bahwa Kartini adalah "rekayasa" atau "buatan Belanda".

Nasionalisme dalam diri Kartini dapat dikategorikan sebagai humanitarian nationalism (nasionalisme yang humanis), yang menjadi ciri nasionalisme dalam perspektif budaya. Karakter nasionalisme humanis Kartini itu dapat diketahui dari pemikiran-pemikirannya yang menjunjung tinggi harkat dan martabat bangsanya. Walaupun dalam ide-idenya yang cemerlang itu tidak dapat ditemukan konsep ideologis tentang bangsa dan negara bangsa (negara nasional), dalam surat-suratnya telah tersirat bahwa Kartini 
memiliki ideologi "Cinta Bangsa dan Tanah Air," "Menjunjung Tinggi Derajat Kemanusiaan", serta "Memperjuangkan Kemajuan Rakyat Bumiputera".

Kartini berjuang tanpa dukungan massa atau pun organisasi. Hanya suratmenyurat dengan kemampuan sastra yang sangat menyentuh serta menggugah semangat yang dapat ia gunakan sebagai media untuk mengekspresikan pemikirannya guna memperbaiki dan memajukan kehidupan rakyat bumiputera di Hindia Belanda (Indonesia). Betapa Kartini merasakan kepedihan mendalam ketika menyaksikan dan mengalami poligami, kebodohan masyarakat bumiputera, konflik sosial karena agama, karakter golongan ningrat/bangsawan, dan kebiasaan madat di kalangan penduduk bumiputera, sehingga selama dalam pingitan pemikirannya membuncah dalam tulisan-tulisan yang bermakna dan indah. Surat-surat Kartini telah menginspirasi banyak pihak untuk melakukan upaya peningkatan kualitas kehidupan bangsa bumiputra (inlander), yang diposisikan dalam stratifikasi masyarakat paling rendah di Hindia Belanda. "Door Duisternis Tot Licht." (Habis Gelap Terbitlah Terang), yang pertama kali diumumkan pada tahun 1911, telah menginspirasi masyarakat bumiputera di Indonesia untuk melakukan gerakangerakan perempuan antara lain: Puteri Mardika \{Jakarta, 1912\}, Kautaman Istri \{Tasikmalaya, 1913\}, Aisyiah \{Yogyakarata, 1917\}, Kongres Perempuan Indonesia pada 22 Desember 1928. Pemikiran-pemikiran Kartini itu telah menjadi dasar ideologis untuk mencapai kemajuan. Oleh karena itu sangatlah layak, jika disematkan sebutan bagi Kartini sebagai "Sang Penyibak Fajar Nasionalisme Indonesia" serta "Diplomat Kebudayaan yang Andal."

\section{Daftar Pustaka}

Abdullah, Taufik, Nasionalisme \& Sejarah, Bandung: Satya Historika, 2001.

Abendanon, Jacques Henrij, "Bevordering van Het Onderwijs van Meisjes Behoorende tot de Inheemsche Bevolking van NederlandschIndië”, dalam Bijdrage in de Praeadviezen van het Koloniale Onderwijs Congres.

Alfian (ed.), Persepsi Masyarakat Tentang Kebudayaan, Jakarta: PT Gramedia, 1985.

Anderson, Benedict, Imagined Communities Reflections on The Origin and Spread of Nationalism, London: Thetford Press Limited, 1983.

Blumberger, J.Th. Petrus, De Nationalistische Beweging in Nederlandsch Indië, DordrechtHolland: Foris Publications, 1987.

Darmanto JT dan Sudharto PH, Mencari Konsep Manusia Indonesia Suatu Bunga Rampai, Jakarta: Penerbit Erlangga, 1986.

Eerste Jaarverslag Der Kartini Vereeniging in Nederlandsch Indië 1914/1914.

Hayes, Carlton J. H., The Historical Evolution of Modern Nationalism, New York: The Macmillan Company, 1931.

Kartini, R.A. Habis Gelap Terbitlah Terang, terjemahan oleh Armijn Pane, Jakarta: Balai Pustaka, 1949.

Kartodirdjo, Sartono. 1993. Pembangunan Bangsa tentang Nasionalisme, Kesadaran dan Kebudayaan Nasional, Yogyakarta: Aditya Media.

Koentjaraningrat. 1974. Kebudayaan Mentalitet dan Pembangunan. Jakarta: PT Gramedia, 1974.

Kohn, Hans, Nasionalisme Arti dan Sejarahnya, Jakarta: PT Pembangunan dan Penerbit Erlangga, 1984. 
Mangoenkoesoemo, Goenawan, "De Geboorte van Boedi Oetomo" dalam Soembangsih Gedenkboek Boedi Oetomo 1908, 20 Mei 1918.

Nagasumi, Akira, Bangkitnya Nasionalisme Indonesia Budi Utomo 1908-1918, Jakarta: PT Grafiti Press \& KITLV, 1989.

Riff, Michael A., Kamus Ideologi Politik Modern, Yogyakarta: Pustaka Pelajar, 1995.

Priyanto, Hadi, Kartini Pembaharu Peradaban, Jepara: Fortsastran, 2010.

Ricklefs, M.C. A History of Modern Indonesia, Houndmills, Basingstoke, Hampshire and London: Macmillan Education LTD, 1981.

Romein, J.M., Aera Eropa Peradaban Eropa Sebagai Penyimpangan dari Pola Umum, Jakarta: NV Ganaco, 1956.

Satjipto Rahardjo. 1986. "Gambaran Tentang Manusia dari Sudut Sosiologi", dalam Darmanto JT dan Sudharto PH, Mencari Konsep Manusia Indonesia Suatu Bunga Rampai (Jakarta: Penerbit Erlangga, 1986), hlm. 69.

Sinar Djawa, 25 Oktober 1917.

Rush, James R., Opium To Java, Jawa Dalam Cengkeraman Bandarbandar Cina, Indonesia Kolonial 1860-1910, Yogyakarta: Mata Bangsa, 2000.

Suyatno. 1985. "Kesadaran Sejarah dan Pembinaan Bangsa," makalah disampaikan dalam Seminar Sejarah, Jurusan Sejarah. Semarang: Fakultas Sastra Universitas Diponegoro.

Toer, Pramoedya Ananta, Panggil Aku Kartini Saja, Jakarta: Lentera Dipantara, 2007.

Verslag Van De Toestand Der Gemeente Semarang Over 1917.

Warsito, Tulus, dan Yuni Kartikasari, Diplomasi Kebudayaan Konsep dan Relevansi Bagi Negara
Berkembang Studi Kasus Indonesia, Yogyakarta: Ombak, 2007.

Wertheim W.F., Masyarakat Indonesia dalam Transisi, Kajian Perubahan Sosial, terjemahan dari Indonesian Society in Transition, A Study Of Social Change, Yogya: PT Tiara Wacana, 1999.

1 Eerste Jaarverslag Der Kartini Vereeniging in Nederlandsch Indië 1914/1914, hlm. 22. Periksa juga Verslag Van De Toestand Der Gemeente Semarang Over 1917,hlm. 356

5 (http://kristindiany .blogspot.co.id/2014/11/organisasiwanita).

6 (https://id-id.facebook.com)

7 Benedict Anderson, Imagined Communities Reflections on The Origin and Spread of Nationalism, London: Thetford Press Limited, 1983), hlm. 15.

8 Taufik Abdullah, Nasionalisme \& Sejarah (Bandung: Satya Historika, 2001), hlm. 49.

9 Sinar Djawa, 25 Oktober 1917.

10 Hans Kohn, Nasionalisme Arti dan Sejarahnya ( Jakarta: PT Pembangunan dan Penerbit Erlangga, 1984) hlm. 75; periksa juga J.M. Romein, Aera Eropa Peradaban Eropa Sebagai Penyimpangan dari Pola Umum (Jakarta: NV Ganaco, 1956), hlm. 75.

11 (Michael A. Riff, Kamus Ideologi Politik Modern, Yogyakarta: Pustaka Pelajar,2001), hlm. 194.

12 (http://www.culturaldiplomacy.org)

13 Tulus Warsito dan Yuni Kartikasari, Diplomasi Kebudayaan Konsep dan Relevansi bagi Negara Berkembang Studi Kasus Indonesia, Yogyakarta: Ombak, 2007, hlm. 176.

14 Jacques Henrij Abendanon, "Bevordering van Het Onderwijs 
van Meisjes Behoorende tot de Inheemsche Bevolking van Nederlandsch-Indië”, dalam Bijdrage in de Praeadviezen van het Koloniale Onderwijs Congres, hlm. 5.

15 Cuplikan Surat Kartini Kepada Nona Zeehandelaar, 6 November 1899, dalam R.A. Kartini, Habis Gelap Terbitlah Terang, terjemahan oleh Armijn Pane (Jakarta: Balai Pustaka, 1949), hlm. 45-46.

16 Surat Kartini kepada Ny. Abendanon, 24 Agustus 1904, dalam Habis Gelap Terbitlah Terang, terjemahan Armijn Pane, hlm. 206.

17 Surat Kartini kepada Zeehandelaar, 6 November 1899, dalam Habis Gelap Terbitlah Terang, terjemahan Armijn Pane, hlm.4445.

18 Cuplikan surat Kartini kepada Nyonya Abendanon, 21 Januari 1901.

19 James S. Rush, Opium to Java, Jawa Dalam Cengkeraman Bandarbandar Opium Cina, Indonesia Kolonial 1860-1910 (Yogyakarta: Mata Bangsa, 2000), hlm. 59-60.

20 James S. Rush, Opium to Java, hlm. 91. 21 Surat Kartini kepada Zeehandelaar, 25 Mei 1899, dalam R. A. Kartini, Habis Gelap Terbitlah Terang, hlm. 41-42. 